DOI: 10.17805/trudy.2015.4.6

\title{
«ЖИЗНЬ УДАЛАСЬ!» ПРЕДСТАВЛЕНИЯ СТУДЕНТОВ МОСКОВСКИХ ВУЗОВ О ЖИЗНИ
}

\author{
М. С. Короткова \\ (Московский гуманитарный университет)
}

Аннотация: В статье представлен вторичный анализ данных о цеенностных ориентациях студенческой молодежи, представления студентов об удавшейся жизни. Проанализированы показатели эмпирического исследования, проведенного автором в вузах Москвы в 2014 г.

Ключевые слова: иенностные ориентации, представления о жизни, студенчество, студенты московских вузов.

\section{«LIFE IS GOOD!» MOSCOW STUDENTS' IDEAS OF LIFE}

\author{
M. S. Korotkova \\ (Moscow University for the Humanities)
}

Abstract: The article presents a secondary analysis of data on value orientations of student youth, in particular, of their ideas of successful life. Our analysis is based on the empirical data from the study conducted by the author in Moscow in 2014.

Keywords: value orientations, beliefs about life, students, students of Moscow universities.

Студенческая молодежь представляет собой наиболее динамичный и социально перспективный слой общества, его стратегический ресурс. Изучение ценностных ориентаций студенчества имеет большое значение для оценки и прогнозирования перспектив развития общества в целом. Наличие сформированных ценностных ориентаций является показателем зрелости личности, от их уровня во многом зависит социальная, творческая активность личности студента (Стегний, Курбатова, 2009: 74).

Ценностные ориентации определяются как определенные установки, устремления, желания, потребности, материальные и духовных блага, образ жизни, нравственные нормы, выступающие для студенческой группы в качестве целей жизнедеятельности. Ценностные ориентации отражают актуальный статус личности, образуют направленность личности отдельного студента и отражают интересы группы в целом (Мнацаканян, 1999: 321). Такая направленность представляет собой совокупность устойчивых мотивов, лежащих в основе ориентации субъекта в социальной среде 
и его оценок ситуаций (Ильинский, Луков, 2005: 25).

При всем многообразии критериев экономической, территориальной и социально-культурной стратификации студенчеству свойственен общий стиль жизни и особая субкультура. Современное молодое поколение называют поколением «независимости»: оно отличается своим стремлением к достижению высокого положения в обществе, профессиональной карьере, материальному благополучию (Сокурянская, 2003: 176). Здоровье, любовь, счастливая семейная жизнь, интересная работа, финансовая обеспеченность - те терминальные ценности, которые занимают высокие позиции в ориентирах молодежи. Современной молодежи присущи такие качества личности как уверенность, активность, независимость, предприимчивость, решительность, целеустремленность, умение рисковать. Повышается значимость интеллекта и коммуникативных качеств личности (Гневашева, 2014).

По наблюдениям социологов, наиболее значимыми для современного студенчества являются в последнее время ценности личной жизни, а затем идут ценности, помогающие реализации и достижению успеха. Однако, нередки случаи, когда молодые люди ставят карьеру и достижение высокого статуса на первое место, а нравственные и духовные ценности уходят на задний план. Любовь к комфорту и различные удовольствия становятся неким стимулом жизненной активности (Серова, 2012: 213).

Несомненно, традиционные ценности и приоритеты не потеряли свою значимость среди молодежи. Многие молодые люди хотят иметь свою собственную семью, обращаясь к положительному примеру старших поколений и, по оценкам ВЦИОМ, на первом месте в системе ценностных ориентаций у молодых россиян - «хорошая семья, дети», однако все чаще традиционному браку молодежь предпочитает сожительство, что приводит к одинокому материнству, неполным, неблагополучным семьям (Огиенко, 2011: 15-18).

Претерпевают изменения и отношение к дружбе и товариществу, отношение к людям в целом все чаще имеет корыстный характер. Зачастую люди, встречающиеся в жизни, воспринимаются как средства достижении цели, отношения становятся поверхностными, неглубокими в эмоциональном плане (Волосков, 2009: 107).

С января по март 2014 г. нами было проведено эмпирическое исследование «Социальный статус российского студенчества в субъективном измерении» (Короткова, 2014a, 2014b), в рамках которого также исследовались ценностные ориентации студентов, их представления о жизни. Объем выборочной совокупности составил 1633 чел. Выборку составили студенты дневного отделения следующих вузов Москвы:

- Московского гуманитарного университета (МосГУ ответы студентов 
заочного отделения при анализе данного аспекта мы не использовали);

• Национального исследовательского ядерного университета «МИФИ» (НИЯУ МИФИ);

- Московского государственного медицинского университета им. И. М. Сеченова (МГМУ им. И. М. Сеченова);

- Московского государственного медико-стоматологического университета им. А. Е. Евдокимова (МГМСУ им. А. Е. Евдокимова);

- Московского университета МВД России (МосУ МВД);

- Российского экономического университета им. Г. В. Плеханова (РЭУ им. Г. В. Плеханова);

- Национального исследовательского университета Московского энергетического института (НИУ МЭИ);

- Российской академии правосудия (РАП);

- Московского педагогического государственного университета (МПГУ);

- Московского государственного технического университета им. Н. Э. Баумана (МГТУ им. Н.Э. Баумана);

- Московского государственного технического университета радиотехники, электроники и автоматики (МГТУ МИРЭА).

Тип выборки - гнездовая (в каждом вузе опрошено по 150 чел.). В отобранных группах был проведен сплошной опрос методом анкетирования.

В ходе исследования были опрошены студенты, обучающиеся на 100 факультетах по 166 специальностям, соответствующих перечню укрупненных направлений и специальностей, указанных в приказе Министерства образования и науки (Приказ Министерства образования и науки ..., 2013: Электр. ресурс). В исследовании приняли участие студенты 10 государственных и 1 негосударственного вуза, из них: на бюджетной основе обучаются $-68,4 \%$ (1117 чел.), на платной - 27\% (442 чел.). Среди студентов, обучающихся на платной основе 17\% (291 чел.) - учащиеся государственных вузов.

Примерно одинаково распределились респонденты по половому признаку: 52\% девушек и 49\% юношей. Базу исследования составили студенты в возрасте от 18 до 21 года. В своем большинстве (95\%) студенты не состоят в браке, только 5\% отметили, что женаты или замужем. Что касается места рождения учащихся, то $42 \%$ студентов - приезжие из других городов и областей России, москвичи составили 33\% опрошенных, жители Подмосковья - 16\% респондентов, граждане СНГ - 6,2\%, граждане других стран $-1,5 \%$.

Ценностные ориентации респондентов рассматривались, прежде всего, через представления респондентов об удавшейся жизни. Возможность выбрать до 5 вариантов ответа, а также представить мнение за пределами 
формализованной части шкалы (вопрос полузакрытый) дает довольно ясное представление об общей направленности ценностного выбора.

Анализ результатов исследования показал: фразу «Жизнь удалась, если...» большинство студентов завершили такими вариантами ответов, как «...здоров я и мои близкие», «...имею хорошую семью» (см. таб. 1). Более половины студентов считают жизнь удавшейся при условии, что они работают на интересной и любимой работе (58\%). Студенты считают важным материальный фактор - вариант ответа «достаточно обеспечен» выбрала половина респондентов. Для 40\% опрошенных жизнь удалась, если они много путешествуют. Свобода и независимость, спокойствие и отсутствие неприятностей отмечают около трети опрошенных.

На средний уровень ценностной шкалы попадают ценности личной автономности, свободы (33\%). Стремление к независимости сопровождается тревогой за личную безопасность (32\%). Статусные ценности продолжают занимать одно из последних мест в шкале ценностных установок (27\%). Их опережает стремление к независимости и свободе, сопровождающееся тревогой за личную безопасность.

Одинаково низки альтруистические настроения («жить не для себя, а для других» - 13\%) и показатели гражданской активности («участвую в общественной жизни, решаю общественные проблемы» - 9,5\%).

В варианте ответа «другое» респонденты дописывали свои варианты ответов. Среди полученных мнений: «смогла достичь поставленных целей, принесла пользу обществу, внесла вклад в историю того, чем занимаюсь», «если я доволен жизнью и не жалею ни о чем из сделанного», «просто чувствую счастье и ни о чем не жалею», «ощущаю состояние внутренней гармонии» и др.

\begin{tabular}{|l|c|c|c|}
\multicolumn{1}{|c|}{ Продолжите фразу: "Жизнь удалась, если я..." } & \multicolumn{3}{|c|}{ ваи пол } \\
\cline { 2 - 4 } & мужской & женский & Bсего \\
\hline достаточно обеспечен(а) & 48,5 & 53,1 & 50,9 \\
\hline имею хорошую семью & 65,9 & 76,7 & 71,5 \\
\hline здоров(а) и здоровы мои близкие & 71,3 & 81,7 & 76,7 \\
\hline $\begin{array}{l}\text { имею постоянную работу и гарантированное } \\
\text { будущее }\end{array}$ & 39,6 & 45,1 & 42,5 \\
\hline работаю на интересной и любимой работе & 51,3 & 64,8 & 58,3 \\
\hline $\begin{array}{l}\text { имею хорошее образование, я - специалист своего } \\
\text { дела }\end{array}$ & 24,8 & 29,9 & 27,5 \\
\hline имею много друзей & 30,3 & 31,4 & 30,9 \\
\hline $\begin{array}{l}\text { занимаю высокое положение в обществе, меня } \\
\text { уважают }\end{array}$ & 26,0 & 27,3 & 26,7 \\
\hline люблю и любим(а) другими & 41,0 & 60,7 & 51,2 \\
\hline живу не для себя, а для других & 15,3 & 10,8 & 13,0 \\
\hline $\begin{array}{l}\text { участвую в общественной жизни, решаю } \\
\text { общественные проблемы }\end{array}$ & 9,1 & & \\
\hline много путешествую & 30,7 & 50,4 & 9,5 \\
\hline свободен(а) и независим(а) & 34,1 & 31,4 & 32,7 \\
\hline спокоен(а) и вокруг нет никаких неприятностей & 28,8 & 34,1 & 31,5 \\
\hline живу в экологически чистом районе & 12,3 & 13,1 & 12,7 \\
\hline
\end{tabular}

Таблица 1. Распределение ответов на вопрос: «Продолжите фразу “Жизнь удалась, если я... “,,$\%$

В определении ценн О С ор иент ацй замечены некоторые гендерные кор- 
реляции: число выборов пункта «любить и быть любимым» у девушек на 20\% больше, чем у юношей. Для девушек также более важно наличие семьи (77\%), нежели для юношей (66\%). Интересная и любимая работа опять-таки в большей степени представляет ценность для девушек (65\%), нежели молодых людей (52\%). Путешествия в жизни важны для половины опрошенных девушек и трети юношей.

С позиции инструментальной ценности рассматривается образование: по результатам исследования, более половины студентов московских вузов рассматривают образование как одновременную возможность обеспечить себе материальный достаток в будущем и стремление стать высококвалифицированным специалистом.

Образовательная компонента социального статуса более ценна для девушек, нежели для юношей. С высшим образованием связывают самореализацию 52\% девушек, 34\% юношей, жизненный успех, соответственно, 58\% и 44\%, материальный достаток в будущем - соответственно 63\% и 51\%.

Таким образом, представления о стандартах удавшейся жизни у студентов московских вузов расположились по следующей иерархии: собственное здоровье и здоровье близких (77\%), семья (72\%), интересная и любимая работа (58\%), любовь (51\%), деньги (51\%). Данные ценности являются цементирующим условием жизненного успеха личности, гарантией высокого социального статуса.

Приоритетность ценности семьи можно обосновать разными обстоятельствами: универсальностью самой ценности, возрастной и социальной спецификой студенческой группы (еще существующая зависимость студентов от благополучия их родительской семьи дополняется ориентацией на успешное создание семьи собственной). К категории лидирующих ценностей, наряду с ценностями семьи, относится и ценность здоровья, далеко не всегда подразумевающая собой практическую реализацию в повседневной практике.

Значительная часть студентов соотносит успех в жизни с интересной, любимой работой, в которой будет реализовываться и совершенствоваться приобретенный в университете образовательный статус. Работа, деньги, свое дело, наличие своего бизнеса - отражение как молодежного прагматизма, так и рыночного меркантилизма. Вряд ли за это можно осуждать студенческую молодежь: сложное материальное положение многих студентов, отсутствие достаточных мер социальной защиты этой социальной группы предопределяет устойчивость материальных ценностей.

Интеграция молодежи в современное общество преимущественно происходит через систему высшего профессионального образования и его ценность в достижении высоких статусных позиций неоспорима. 


\section{СПИСОК ЛИТЕРАТУРЫ}

Волосков, И. В. (2009) Особенности социализации учащейся молодежи // Социологические исследования. № 6. С. 107-109.

Гневашева, В. А. (2014) Добродетель и ценность как тезаурусные константы // Знание. Понимание. Умение. № 2. С. 117-124.

Ильинский, И. М., Луков, В. А. (2005) Московский вуз глазами студентов: по материалам опроса студентов государственных и негосударственных вузов Москвы. М. : Изд-во Моск. гуманит. ун-та. 64 с.

Короткова, М. С. (2014а) Социальный статус студенчества в субъективном измерении: результаты эмпирического исследования // Знание. Понимание. Умение. № 4. С. 108-117.

Короткова, М. С. (2014b) Вторичная занятость как фактор оценки социального статуса студенчества // Известия высших учебных заведений. Социология. Экономика. Политика. № 4 (43). С. 105-110.

Мнацаканян, М. О. (1999) Ценностные ориентации : учебный социологический словарь / под общ. ред. С. А. Кравченко. М. : ИНФРА-М. 315 с.

Огиенко, Т. Ю. (2011) Семья и брак в системе ценностных ориентаций современной молодежи // Материалы VI Международной студенческой электронной научной конференции «Студенческий научный форум». М. : Изд-во Академии Естествознания. 270 с. С. 15-18.

Приказ Министерства образования и науки Российской Федерации от 12 сентября 2013 г. № 1059 г. Москва «Об утверждении Порядка формирования перечней профессий, специальностей и направлений подготовки» (2013) [Электронный ресурс] // Российская газета. 23 октября. URL: http:// www.rg.ru/2013/10/23/perechen-dok.html (дата обращения: 15.10.2014).

Серова, О. Ю. (2012) Проблема формирования смыслообразующих ценностей студенческой молодежи // Материалы всероссийской научнопрактической конференции «Молодежь XXI века». Саратов : Изд-во НАЧОУ ВПО Современной гуманитарной академии. Саратовский филиал. 113 с. С. $61-62$.

Сокурянская, Л. Г. (2003) Ценностный мир студенчества: поколенческие различия // Тезисы докладов и выступлений на II Всероссийском социологическом конгрессе «Российское общество и социология в XIX веке: социальные вызовы и альтернативы» : в 3 т. М. : Логос. Т. 3. 307 с. С. 74-78.

Стегний, В. Н.. Курбатова, Л. Н. (2009) Социальный портрет студенчества в условиях трансформирования российского общества. Пермь: Издво Перм. гос. техн. ун-та. 384 с. 
Короткова Марина Сергеевна - аспирантка кафедры социологии, директор Центра содействия трудоустройству выпускников Московского гуманитарного университета. Адрес: 111395, Россия, г. Москва, ул. Юности, д. 5. Тел.: +7 (499) 374-71-53 Эл. адрес: mosgu_studsovet@mail.ru

Korotkova Marina Sergeyevna, Postgraduate student, Department of sociology; Director, Graduate Career Center, Moscow University for the Humanities. Postal address: 5 Yunosti St., 111395 Moscow, Russian Federation. Tel.: +7 (499) 374-71-53 Email: mosgu_studsovet@mail.ru 